\title{
ARTICLE
}

\section{In Situ Proteomic Analysis of Glioblastoma Multiforme: A Translational Approach to Improve Prognostic/Diagnostic Routines}

\author{
Anally Ribeiro da Silva Menegasso', Marcel Pratavieira', Lucilene Delazari dos Santos², \\ Flávio de Oliveira Lima², Marcelo Padovani T. Moraes ${ }^{3}$, Marco Antonio Zanini \\ Mario Sergio Palma ${ }^{1 *}$ (iD \\ ${ }^{1}$ Institute of Biosciences, Department of Basic and Applied Biology, Center of the Study of Social Insects, São \\ Paulo State University (UNESP), Rio Claro, SP, Brazil \\ ${ }^{2}$ Center for the Study of Venoms and Venomous Animals (CEVAP), Sao Paulo State University (UNESP), \\ Botucatu, SP, Brazil \\ ${ }^{3}$ Botucatu Medical School (FMB) - São Paulo State University (UNESP), Botucatu, SP, Brazil \\ ${ }^{*}$ Correspondence: Prof. Dr. Mario Sergio Palma. CEIS-IBRC- UNESP, Av. 24A n 1515, Bela Vista - 13506-900, \\ Rio Claro, SP, Brazil
}

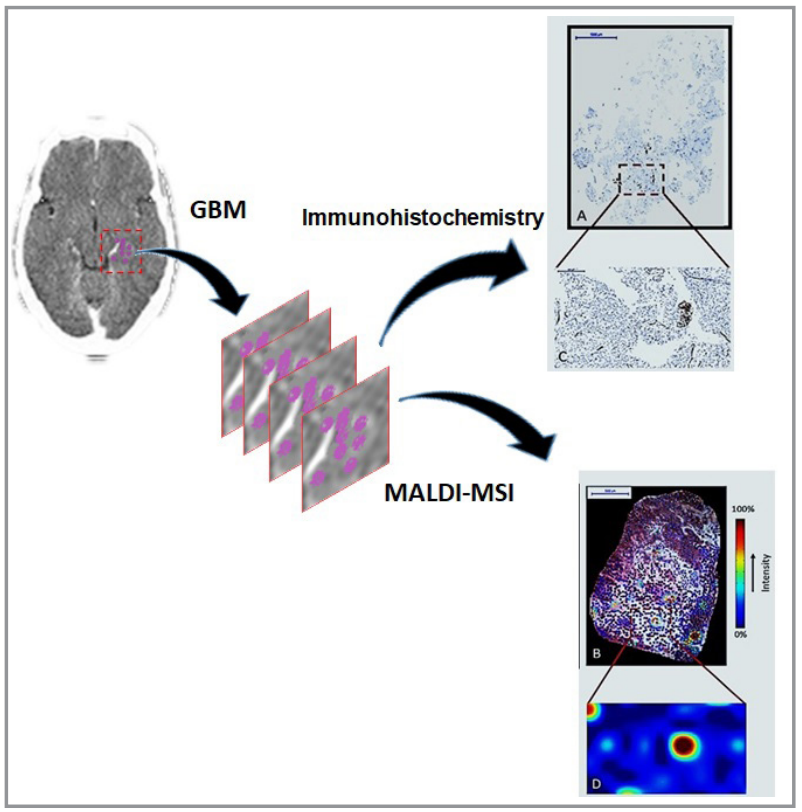

In order to evaluate the use of matrix-assisted laser desorption ionization (MALDI) Mass Spectral Imaging (MSI) to Glioblastoma (GBM) studies, some sections of formalin fixed paraffin embedded samples of GBM tumors were submitted to classical immunoassays, to define the profile of distribution of some classical and well recognized molecular markers of GBM grade IV (Ki-67, S100, Glial GFAP, CD31 and CD34), while other sections of the same samples were submitted to intissue proteomic analysis by MALDI MSI, and both results compared to each other. The overlapping of the MALDI spectra obtained for the tryptic peptides with the immunohistochemical reactions of each marker protein were used to build a distribution map of the marker proteins all over the GBM tissue section. The results revealed a high correlation between both methods, indicating that MALDI MSI has enough sensitivity to be compared to the immunohistochemical methods, as well is sufficiently reliable to be used in biomarkers identification.

Keywords: MALDI-TOF MS, MALDI Imaging, Tumor biomarkers, Glioblastoma multiforme, In situ proteomics.

Cite: Menegasso, A. R. S.; Pratavieira, M.; dos Santos, L. D.; Lima, F. O.; Moraes, M. P. T.; Zanini, M. A.; Palma, M. S. In Situ Proteomic Analysis of Glioblastoma Multiforme: A Translational Approach to Improve Prognostic/Diagnostic Routines. Braz. J. Anal. Chem., 2020, 7 (29), pp 64-83. doi: http://dx.doi.org/10.30744/brjac.2179-3425.AR-41-2020 


\section{INTRODUCTION}

GBM is a very common malignant primary brain tumor in adults, being one of the most lethal human cancers [1]. In US there are about 50,000 GBM patients and approximately 10,000 new cases are diagnosed annually [2-4]. In addition to this, GBM tumors are extremely resistant to radiation and chemotherapy [1,5]; even after aggressive surgical resection GBM patients survive only a few months [6]. GBMs are malignant gliomas arising from glial cells of the brain, and according to World Health Organization classification system, these types of gliomas are classified based on the resemblance of their histology and immunohistochemical profile to the presumed cells of origin [7]. The tumors are then graded according to the histological features associated with biological aggressiveness (i.e., mitotic figures, necrosis, vascular endothelial hyperplasia) [8]. According to this classification, grade I represents the least severe pathology, while grade IV corresponds to the most severe one. The diagnosis and grading of these gliomas take into account the understanding about the heterogenous histology and its relationship with a complex molecular scenario of these tumors [8].

Mutations suffered by normal cells are important for the classification of these tumors, and may be used to track the progress of the gliomagenesis [9]. Clinically, some patients may present a grade IV lesion which developed de novo from normal glial cells suffering mutations (primary GBM), while other patients may present GBM tumor which evolved from the progression of lower grade gliomas (secondary GBMs) [8]. Despite both GBM tumors are graded IV, they present distinct correlation with different molecular markers [10]. Secondary GBMs are rare, and accounts for less than 10\% of GBMs cases; their unique immunohistochemical profile, and the clinical course of these tumors have clarified the understanding about GBM as a heterogeneous disease [10].

The cellular and histologic heterogeneity, as well the genetic and clinical differences amongst the GBM patients, and the difficulties to access fresh-frozen samples of tumor tissues, limited initially the contributions of proteomics to the study of GBM. This situation evolved due to the improvement of proteomic techniques, and availability of novel cellular and technical tools to overcome cell heterogeneity of these tumors [11]. Thus, as example, the novel techniques of quantitative proteomics permitted to investigate the serum proteomes of GBM patients, resulting in the identification of potential biomarkers to monitor patient responses to therapy [12]. Proteomics also contributed for understanding of gliomas pathobiology, as well identifying novel therapeutic targets for this disease; thus, as examples were reported the presence of ceruloplasmin, vitamin $D$ binding protein, and serum amyloid $P$, which were not reported directly in the context of GBM formation, but presented a good correlation with tumor growth and metastasis formation [12].

The expression (or repression) of some important proteins are critical for understanding GBM tumorigenesis; the identification (or not) of these proteins have been used as criteria for diagnosis and prognosis of the disease [9]. The proteins reported as molecular markers of GBM tumorigenesis includes proteins such as epidermal growth factor receptor (EGFR), platelet-derived growth factor receptor (PDGFR) [13], O-6-methylguanine-DNA-methyltransferase (MGMT), p53, Isocitrate dehydrogenase gene 1 and 2 (IDH1/2), phosphatase and tensin homolog (PTEN), phosphoinositide 3-kinase (PI3K) [9] amongst many others. Since the GBMs are histologically heterogeneous, a series of different molecular makers are used to obtain the immunohistochemical profile of each tumor, for the purpose of diagnosis and prognosis. The most usual markers used are the proteins Ki-67 [14], S100, Glial fibrillary acidic protein - GFAP [15], CD31 and CD34 $[16,17]$.

Mass spectrometry emerged as a very attractive method for the examination of proteins in different types of extracts and tissue sections. Currently, MALDI MSI associates the classical histology and in situ proteomics, permitting to map specific proteins into the organizational structure of a tissue section, at level of cutting edge for detection of proteins and peptides $[18,19]$. The development of MALDI MSI provided a powerful tool for proteomic research in pathology, enabling the identification and relative quantification of proteins directly in their histological framework. The matching of histomorphology with this level of proteomic analysis opens wide possibilities for a true revolution in this area of medical knowledge [20-22]. In MALDI MSI the proteins considered as molecular markers can be detected and identified without the requirement 
of specific and highly selective antibodies (as required by the immunoassays). Because of this feature, the technique may be used both as an independent method for detecting and mapping the molecular maker in GBM tissue section, as well to validate the results of immunoassays. In order to evaluate the application of MALDI MSI to the study of GBM, some sections of formalin fixed paraffin embedded samples of GBM were submitted to classical immunohistochemistry, for defining the profile of molecular markers of GBM grade IV (Ki-67, S100, Glial GFAP, CD31 and CD34). Meanwhile, other sections of the same samples were submitted to in-tissue proteomic analysis and MALDI MSI, and both results compared to each other. The results revealed a great correlation between both methods, indicating that MALDI MSI has enough sensitivity to corroborate the immunehistochemical methods, as well is sufficiently reliable to be used in biomarkers identification.

\section{MATERIAL AND METHODS Histopathology methods}

Processing the tissue samples

The tissues of human glioblastoma were obtained from the surgical pathology routine of the Department of Pathology of the Hospital of Clinics of the Faculty of Medicine of Botucatú (HCFMB), in conjunction with the Neurosurgery service of the same hospital. The project was approved by the Research Ethics Committee (CEP) of Botucatu Medical School UNESP (CEP 378/2012, protocol CEP 4305/2012). Frozen sections of non-formalin-fixed material were used for shotgun proteomic analysis, and histological sections of formalin fixed paraffin embedded GBM tissues were used for immunohistochemistry and MALDI MSI analysis. Histological sections with $3 \mu \mathrm{m}$ thickness of each block were stained by the hematoxylin-eosin technique, and reviewed by a pathologist for the evaluation of histopathological findings.

\section{Immunohistochemistry}

The histological sections, with the respective positive and negative controls, were submitted to examination using an automated immunohistochemical system, with antigenic recovery mode. TPLink $\left(D^{\circledR} \mathrm{B}^{\circledR}\right)$. The incubation, development and counterstaining were performed with an AutoStainer Link48 $\left(\right.$ Dako $\left.{ }^{\circledR}\right)$, using high sensitivity polymer and FLEX antibodies ready for use. The primary antibodies used were acquired from DAKO/AGILENT for using in Autostainer Link 48 system as follows: Glial Fibrillary Acidic Protein (GFAP) polyclonal rabbit anti-human), Ki-67 (clone MIB-1 mouse anti-human), CD31 (clone JC70A mouse anti-human), CD34 (clone QBEnd 10 mouse anti-human), and S100 (clone IR504 mouse anti-human). The slides were mounted on Entellan resin (Sigma).

\section{Interpretation of the labeling reactions}

The cases presenting any expression in the target were considered positive cells for the immunohistochemical markers GFAP, CD34, CD31, S100 and Ki-67. For interpretation of CD31 and CD34 any membrane or cytoplasmic staining was considered. For the interpretation of GFAP, any cytoplasmic and fibrillary immunostaining was considered positive, meanwhile for Ki-67 any nuclear labeling was considered. The interpretation for S100 protein, considered any nuclear or cytoplasmic labeling.

\section{Mass spectrometric analysis and data treatment}

GBM tissue section preparation for analysis

The fresh GBM tumors were frozen and maintained in the ultra-freezer at $-80^{\circ} \mathrm{C}$ The frozen tumors were sliced at $12 \mu \mathrm{m}$ thick sections using a cryostat at $-20{ }^{\circ} \mathrm{C}$ (LEICA CM1850). Subsequent histological sections were analyzed immediately through histological staining technique by hematoxylin and eosin (H\&E). The slices analyzed by MALDI-MSI were previously washed successively with $70 \%(\mathrm{v} / \mathrm{v})$ ethanol, subsequently with $90 \%(\mathrm{v} / \mathrm{v})$ ethanol during one minute in each solution, for the elimination of salts and lipids present in the samples. Subsequently, the histological sections were subjected to desiccation for 30 minutes under ambient temperature in a vacuum sealed desiccator containing silica gel as desiccant. 
Some slices were submitted to staining with H\&E for localization of GBM structures. For this technique, the slice preparations were submerged in $95 \%$ (v/v) ethanol during 20 minutes, washed under running water and then stained with hematoxylin for 20 seconds.

After this procedure, the slides were washed with distilled water. They were then stained with eosin for 20 seconds more and washed with distilled water. At the end of the process, the slides were rinsed with solutions of $95 \%(\mathrm{v} / \mathrm{v})$ ethanol for removal of excess dye and in Xylol solutions. The digital images of the tissue sections were generated through a microscope Olympus BX51TF, connected to a camera Olympus U-LH100HG.

In the analyses of the tryptic digests, trypsin deposition was carried-out through a chemical printer CHIP-1000 (Shimadzu). The printer was programmed to generate a micro-arrangement of about 15,000 spots/tissue section analysis, where each point of application of the matrix (and trypsin solution) solution was spaced by $200 \mu \mathrm{m}$ from each other (from center to center in lateral resolution), totaling 100 spots/ $\mathrm{mm}^{2}$ of histological section. Initially in each spot was applied $20 \mathrm{~nL}$ of a solution containing $20 \mathrm{mg} / \mathrm{mL}$ of trypsin in $20 \mathrm{mM} \mathrm{NH}_{4} \mathrm{HCO}_{3}(\mathrm{pH} 8.0)$ and incubated during $2 \mathrm{~h}$, at $37^{\circ} \mathrm{C}$. The section was then incubated for $90 \mathrm{~min}$ in a humid atmosphere at $37^{\circ} \mathrm{C}$. Next, a solution containing $10 \mathrm{mg} / \mathrm{mL}$ of cinnamic acid (CHCA) in $50 \%(\mathrm{v} / \mathrm{v})$ acetonitrile (containing 1\% (v/v) trifluoroacetic acid (TFA)) was used as a matrix for analysis of the tryptic digests, being applied $500 \mathrm{pL}$ (5 drops of $100 \mathrm{pL}$ ) of matrix/point solution. After the application of the matrix, the histological sections were submitted to the process of desiccation during 15 minutes, under room temperature. Planar coordinates ( $x$ and $y$ ) created by the ChIP-1000 were saved and exported to the mass spectrometer.

\section{Proteome approach}

\section{LC-MS and LCMS ${ }^{n}$ analysis}

One slice of GBM tumor (12 $\mu \mathrm{m}$ thick sections) was homogenized in ( $5 \mu \mathrm{g}$ tissue) in $300 \mu \mathrm{L}$ of $50 \mathrm{mM}$ ammonium bicarbonate, $\mathrm{pH} 7.9$, and centrifuged at $10.000 \mathrm{xg}$ during $10 \mathrm{~min}$ at $4{ }^{\circ} \mathrm{C}$. The supernatant was dried using a speed-vac system (Edwards Co,), and maintained at $-80^{\circ} \mathrm{C}$ until be analyzed. The samples were solubilized in $50 \mathrm{mM}$ ammonium bicarbonate, $\mathrm{pH} 7.9$, containing $7.5 \mathrm{M}$ urea and incubated for 60 min at $37^{\circ} \mathrm{C}$ to denature the proteins, which were then reduced with $10 \mathrm{mM}$ DTT at $37^{\circ} \mathrm{C}$ for $60 \mathrm{~min}$. After this treatment, the proteins were alkylated with $40 \mathrm{mM}$ iodoacetamide at $25^{\circ} \mathrm{C}$ for $60 \mathrm{~min}$ in the dark. The samples were diluted two-fold with $100 \mathrm{mM}$ ammonium bicarbonate, $\mathrm{pH} 7.8$, and $1 \mathrm{M}$ calcium chloride was added to the samples to a final concentration of $1 \mathrm{mM}$. Non-autolytic trypsin (Promega) was added to the denatured protein solution (1:50 trypsin : protein, w/w) and incubated for $18 \mathrm{~h}$ at $37^{\circ} \mathrm{C}$. The samples were frozen in liquid nitrogen to interrupt the enzymatic digestion. The digested samples were desalted using an SPE C18 column (Discovery DSC-18, SUPELCO, Bellefonte, PA, USA) conditioned with MeOH, rinsed with $1 \mathrm{~mL} 0.1 \%$ TFA and washed with $4 \mathrm{~mL}$ of $0.1 \%(\mathrm{v} / \mathrm{v})$ TFA / $5 \%(\mathrm{v} / \mathrm{v})$ ACN. Peptides were eluted from the SPE column with $1 \mathrm{~mL}$ of $0.1 \%$ TFA $/ 80 \% \mathrm{ACN}$ and concentrated to dryness using a Speed-Vac. The digested samples were stored at $-80^{\circ} \mathrm{C}$ until needed for analysis; the tryptic peptides were solubilized in $50 \% \mathrm{ACN}$ and subjected to LC-MS and $\mathrm{MS}^{n}$ analysis. The samples were solubilized in $100 \mu \mathrm{L}$ of $50 \%(\mathrm{v} / \mathrm{v})$ ACN and fractionated in an LC-MS system using an X-Bridge BEH $130 \mathrm{C}-18$ column $(100 \mathrm{~mm} \times 2.1 \mathrm{~mm}$; $3.5 \mu \mathrm{m}$ ) (Waters, Massachusetts, USA) at a flow rate of $200 \mu \mathrm{L} / \mathrm{min}$. Elution was performed under gradient conditions from 5 to $95 \%(\mathrm{v} / \mathrm{v}) \mathrm{ACN}$ (containing $0.1 \%(\mathrm{v} / \mathrm{v}) \mathrm{TFA}$ ) between 0 and $95 \mathrm{~min}$ at $30^{\circ} \mathrm{C}$. The eluent was monitored at $215 \mathrm{~nm}$ with a UV-DAD detector, mod. SPD-M10A (SHIMADZU, Kyoto, Japan) coupled to an IT-TOF/MS and $\mathrm{MS}^{n}$ mass spectrometer system equipped with an electrospray ionization source

(Shimadzu, Kyoto, Japan). Spectra were acquired in positive mode, with activation of data dependent acquisition (DDA), which permits an automatic switching from MS to MS2 mode. The electrospray voltage was set to $4.5 \mathrm{kV}$, the $\mathrm{CDL}$ temperature was set to $200^{\circ} \mathrm{C}$, the block heater temperature was adjusted to $200{ }^{\circ} \mathrm{C}$, the nebulizer gas $\left(\mathrm{N}_{2}\right)$ flow was $1.5 \mathrm{~L} / \mathrm{min}$, the trap cooling gas $(\mathrm{Ar})$ flow was $95 \mathrm{~mL} / \mathrm{min}$, the ion trap pressure was $1.7 \times 10^{-2} \mathrm{~Pa}$, the TOF region pressure was $1.5 \times 10^{-4} \mathrm{~Pa}$, and the ion accumulation time was $50 \mathrm{~ms}$. The top five ions from each MS spectrum were selected as precursors (Top N) for fragmentation 
in $\mathrm{MS}^{2}$, as typically used in DDA experiments. The collision energy was set at $35 \%$ both for $\mathrm{MS}^{2}$ and $\mathrm{MS}^{3}$, and the collision gas set to $20 \%$. Auto-tuning was performed in the presence of Na-TFA solution (10 mM $\mathrm{NaOH}+0.1 \%(\mathrm{v} / \mathrm{v})$ at $\mathrm{pH} 3.5)$. The mass spectral resolution was approximately $10,000 \mathrm{FWHM}$, and error was approximately $3.08 \mathrm{ppm}$.

\section{Mass spectrometry conditions for MALDI spectral acquisition}

The tissue section preparation was dried under vacuum during $10 \mathrm{~min}$ and submitted to the acquisition of MALDI spectra in the positive mode, using a MALDI-TOF-TOF instrument mod. AXIMA Performance (Shimadzu Corp., Kyoto, Japan), equipped with a laser SmartBeam system, with the reflectron device activated. The instrument was controlled using the Launchpad v2.8 software (Shimadzu). The setting conditions were: CDL temperature adjusted to $200{ }^{\circ} \mathrm{C}$, block heater temperature at $200{ }^{\circ} \mathrm{C}$, TOF region pressure $1.5 \times 10^{-4} \mathrm{~Pa}$, ion accumulation time $50 \mathrm{~ms}$; helium was used as collision gas. It was applied an accelerating voltage of $20 \mathrm{kV}$ and delayed extraction, peak density of maximum 50 peaks per 200 $\mathrm{Da}$, minimal $\mathrm{S} / \mathrm{N}$ ratio of 10 and maximum peak at 60 . The instrument was calibrated using a standard calibration mixture of ACTH (fragment 18-39), Angiotensin II and P14R. The MS spectra were acquired in the $\mathrm{m} / \mathrm{z}$ range $700-3600$, with the laser power set to $70 \%$, adjusted to perform delayed extraction; the density of peaks was set at 50 for each 200 peaks presenting $\mathrm{S} / \mathrm{N}$ ratio $\geq 10$. The spectra were acquired with 50 shots per movement from the center of each spot, up to a distance of $50 \mu \mathrm{m}$ straight, performing a total of 250 laser shots per spot. Under the conditions reported above the error obtained was $3.08 \mathrm{ppm}$ and resolution 9,000 FWHM.

\section{Proteins identification}

The proteins identification was performed with the algorithm MASCOT ( $v$ 2.3) to analyze the $\mathrm{MS}^{2}$ spectra, using the protein databank restricted to the genus Homo sapiens (NCBI). The search parameters were set as follows: trypsin was selected as enzyme, one maximum missing cleavage sites selected; peptide mass tolerance was adjusted to 0.3 Da for MS and 0.2 Da for $\mathrm{MS}^{2}$ spectra; carbamidomethyl (C) specified as a fixed modification, and methionine oxidation was selected as a variable modification. After protein identification, an error-tolerant search was performed to detect nonspecific cleavage. The proteins identified after the database search were subjected to additional filtering using Scaffold 4.3.2 (Proteome Software Inc., Portland, OR) to validate the peptide identification and to obtain a false discovery rate (FDR) of less than 1\%; FDR was calculated from forward and decoy matches by requiring significant matches for at least two distinct peptide sequences. According to a Local FDR algorithm implemented in Scaffold, the peptide probability was set to a minimum of $90 \%$, whereas the protein probability was set at $95 \%$. The databanks mentioned above were screened for common external contaminants (laboratory proteins and standards proteins provided through the Global Proteome Machine Organization (http://www.thegpm.org/ crap/index.html). Functional and Gene Ontology (GO) annotations were performed using the algorithm developed by the GO Consortium (http://www.geneontology.org/).

\section{Spectral imaging data processing}

Using of the Launchpad algorithm $\vee 2.8$ (Shimadzu) the raw data (.raw) were converted to the format .$m z X M L$. The images were rebuilt in MSiReader $v 0.05$ algorithm from the data in the format . $m z X M L$, using a mass tolerance of $\pm 0.3 \mathrm{Da}$ and spacing of $250 \mu \mathrm{m}$. In this algorithm, the following parameters were configured: the method used to calculate the intensity displayed in molecular images was the Max of Window (Max); subtraction of noise and background; baseline correction and cubic interpolation of order 5 of the images' pixels.

Molecular images of GBM sections were constructed using the corresponding $\mathrm{m} / \mathrm{z}$ values of the molecular ions from the tryptic fragment peptides of the molecular markers selected, in their monoprotonated form $[\mathrm{M}+\mathrm{H}]^{+}$for each specific molecular marker as described elsewhere [23]. The scale of color used in the border of these images correspond to a semi-quantitative method of representation of molecules distribution in a 
snap-shot of sample collection. The images used to represent the distribution of each molecular marker were built based on the overlapping of the Extract of Individual Ion Chromatogram (XIC) of all the tryptic fragments identified for the marker.

\section{RESULTS AND DISCUSSION}

The GBM section preparation using a chemical printer applied reagents in $25 \mathrm{spots} / \mathrm{mm}^{2}$ of tissue section; considering that the total surface of each section presented $300 \mathrm{~mm}^{2}$, the whole surface of each GBM tissue section was covered by an array of 7,500 spots. Thus, if each spot was shot by 250 laser shots, this means that the complete analysis of each section required $1.875 \times 10^{6}$ laser shots, and consequently the same number of spectra were acquired for the analysis of each GBM tissue section. The tryptic digestion of GBM tissue section, followed by the MS and MS/MS analysis resulted in the detection and reliable sequencing of 166 peptides, which in turn permitted the identification of 25 proteins (shown in Table S.I in Supplementary Material). The identifications were performed using a minimum of two tryptic peptides per protein; the protein scores changed from 33 to 83, with sequence coverage from $3 \%$ to $58 \%$ (Table S.I in Supplementary Material). These proteins probably are the most abundant ones in the tissue slices of GBM tumor cells and/or correspond to the proteins most ionizable from the samples, under the experimental conditions reported in material and methods. The proteins with functions identified by GO analysis were classified into different groups; those apparently related to processes involved with the development of cancer tumors are described as follows:

i) Organization/regulation of the cytoskeleton: Thymosin beta-10, Calponin-2, and Microcephalin, and F-actine capping protein subunit beta;

ii) Adhesion cell-matrix / cellular differentiation: Collagen alpha-1 chain;

iii) Signal transduction: Guanine nucleotide-binding protein G, Cocaine/ amphetamine-regulated transcript protein, RAB3A interacting protein, and Raftlin;

iv) Regulation of T-cell activation: Dual specificity tyrosine-phosphorylation-regulated kinase 1B;

v) Regulation of Immune Response: Tumor necrosis factor receptor superfamily member 17, Ubiquitinassociated and $\mathrm{SH} 3$ domain-containing protein A, Kelch-like protein 6, and serpin-like protein HMSD;

vi) Energetic metabolism: alpha amylase 2B, ATP-synthase subunit-S like protein;

vii) Protein degradation: LON-peptidase N-terminal domain and ring finger protein;

viii) Cel-to-cell communication: cysteine rich PD2-binding protein;

ix) Transcriptional process: host cell factor 2 .

Table S.I in Supplementary Material also shows a small group of proteins (Ki-67, glial fibrillary acidic protein - GFAP, protein S100-A, hematopoietic progenitor cell antigen CD34, and platelet endothelial cell adhesion molecule - CD31) that have been frequently used as markers of proliferation of GBM tumor cells by the pathologists [14-16]. Thus, considering the use of these five proteins in the routine diagnostic of GBM in humans, the images generated for mapping the distribution of these markers all over the GBM section using immunohistochemistry were compared to the images resulting from the application of MALDI MSI protocols to the equivalent tissue sections, as shown in Figures 1 to 5 . The images of these proteins, mapping their pattern of distribution in the GBM tumor section, were generated by overlapping the $\mathrm{m} / \mathrm{z}$ values of all tryptic peptides detected for each marker; the individual spatial distribution was made in a relative scale, using the peak of highest intensity amongst those corresponding to the tryptic peptides of each marker protein.

The Figures $1 \mathrm{~A}$ and $1 \mathrm{~B}$ show the pattern of labelling obtained by immunohistochemistry and the general profile of MALDI MSI, respectively, for the GBM marker CD31 over the GBM tissue section. The Figure $1 \mathrm{C}$ is showing the magnified image of the area assigned by the dashed lines in the Figure 1A; meanwhile, the figure $1 \mathrm{D}$ is showing the magnified image corresponding to the MALDI MSI of the region assigned by a dashed rectangle in Figure 1B. 


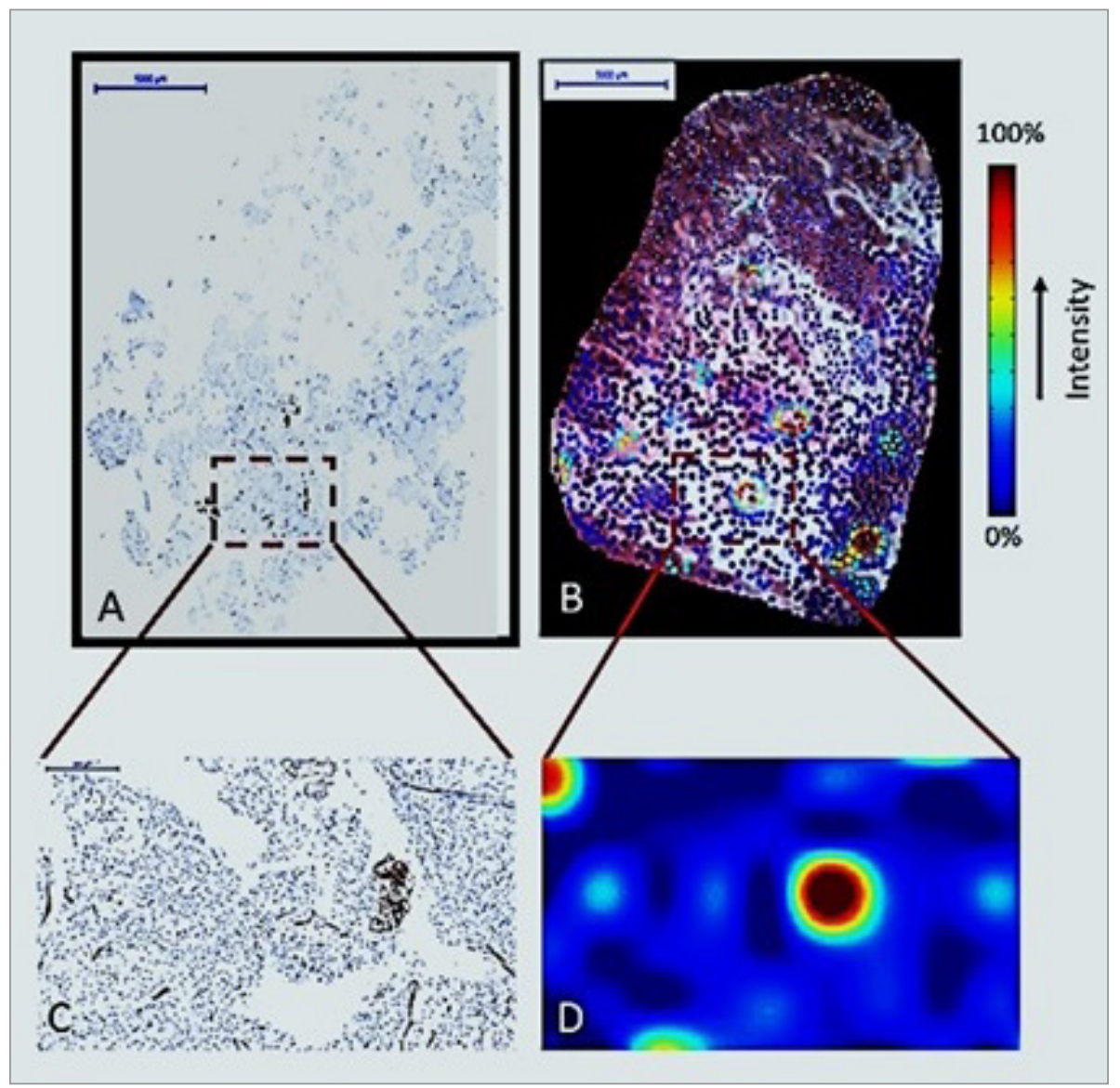

Figure 1. Immunohistochemistry and MALDI-MSI for the molecular marker CD31. Comparative overlapping of images between the immunohistochemistry labeling for CD31 as molecular marker $(A)$, and the molecular mapping of the same biomarker, generated by MALDI Spectral Imaging (B). The selected region in (A) was magnified (C) to show the evident glomeruloid vascular formation, with the reactional endothelial proliferation associated to capillary vessels, characterized by the positive immunohistochemical reaction (brown goldish labeling). In the corresponding figure generated by MALDI Spectral Image (D), the glomeruloid structures are identified by their "hot colors", in the same spatial localization of the positive foci of the immunohistochemical reactions, spaced by negative or less positive areas. The images of CD31 distribution were produced by overlapping of the $m / z$ values of the tryptic peptides detected for this marker: $m / z$ 1244.62 (SLPDWTVQNGK), $m / z 1744.81$ (PELESSFTHLDQGER), $\mathrm{m} / \mathrm{z} 1609.65$ (EQEGEYYCTAFNR), and $\mathrm{m} / \mathrm{z}$ 1198.55 (DTETVYSEVR). The spatial distribution of CD31 was represented quantitatively in a relative scale, shown in the right side of the figure.

The Figures $2 \mathrm{~A}$ and $2 \mathrm{~B}$ show the pattern of labelling obtained by immunohistochemistry and the general profile of MALDI MSI, respectively, for the GBM marker CD34 over the GBM tissue section. The Figure 2C is showing the magnified image of the area assigned by the dashed lines in the Figure 2A; meanwhile, the figure $2 \mathrm{D}$ is showing the magnified image corresponding to the MALDI MSI of dashed rectangle in Figure $2 \mathrm{~B}$. 


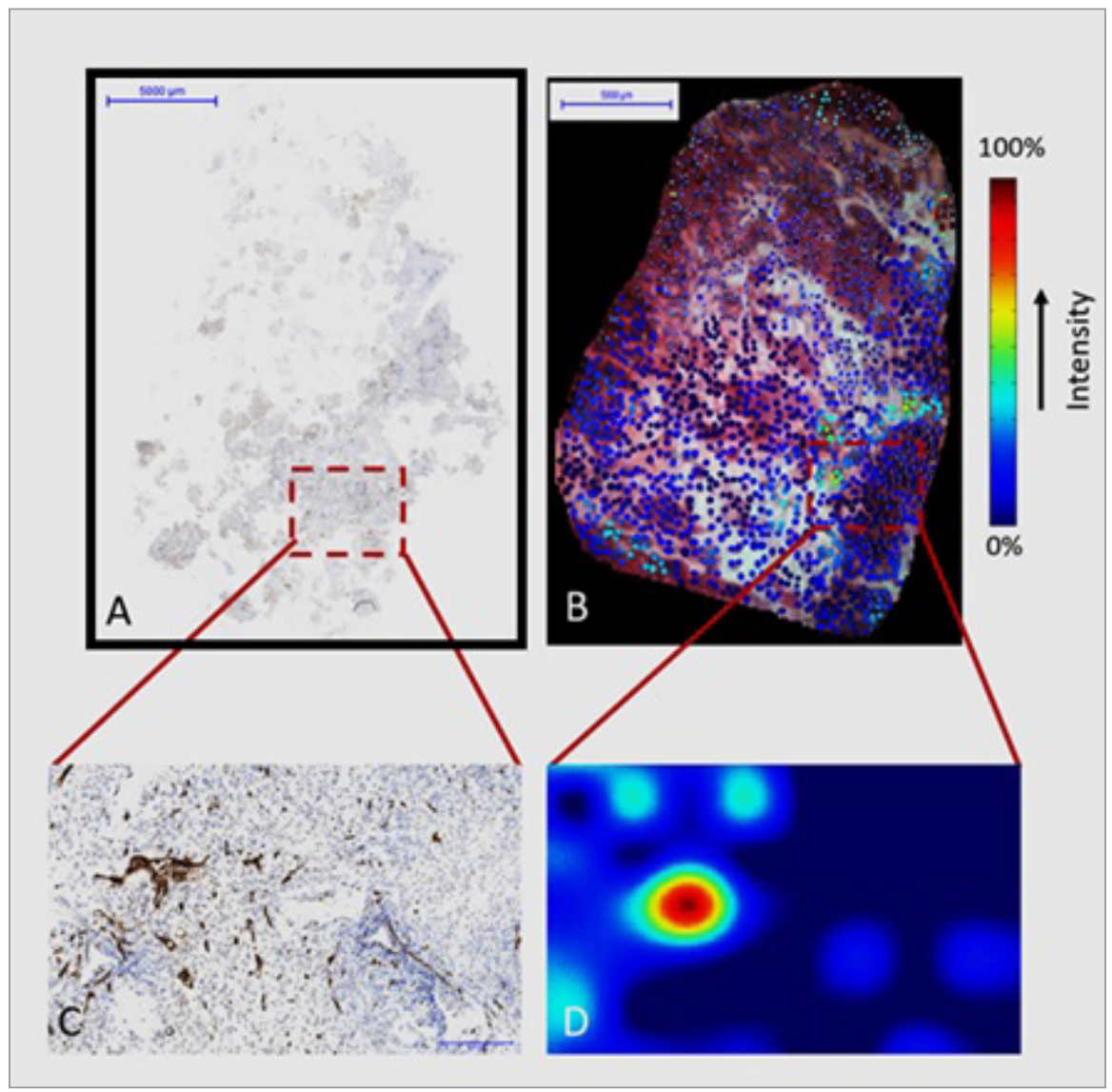

Figure 2. Immunohistochemistry and MALDI-MSI for the molecular marker CD34. Comparative overlapping of images between the immunohistochemistry labeling for CD34 (A), and the molecular mapping of the same biomarker, generated by MALDI Spectral Imaging (B). The selected region in (A) was magnified $(C)$ to show the evident glomeruloid vascular formation, where the reactional endothelial proliferation is associated to capillary vessels, characterized by the positive immunohistochemical reaction (brown goldish labeling). In the corresponding figure generated by MALDI Spectral Image (D), the glomeruloid structures are identified by their "hot colors", in the same spatial localization of the positive foci of the immunohistochemical reactions, spaced by negative or less positive areas. The images of CD34 distribution were produced by overlapping of the $\mathrm{m} / \mathrm{z}$ values of the tryptic peptides detected for this marker: $\mathrm{m} / \mathrm{z} 2348.18$ (PSLSPGNVSDLSTTSTSLATSPTK), $\mathrm{m} / \mathrm{z} 1407.73$ (PYTSSSPILSDIK), m/z 664.34 (TEISSK), m/z 2266.09 (LGILDFTEQDVASHQSYSQK), and $\mathrm{m} / \mathrm{z} 919.42$ (SWSPTGER). The spatial distribution of CD34 was represented quantitatively in a relative scale, shown in the right side of the figure.

The Figures 3A and 3B show the pattern of labelling obtained by immunohistochemistry and the general profile of MALDI MSI, respectively, for the GBM marker GFAP over the GBM tissue section. The Figure 3C is showing the magnified image of the area assigned by the dashed lines in the Figure 3A; meanwhile, the figure 3D is showing the magnified image corresponding to the MALDI MSI of dashed rectangle assigned in Figure 3B. 


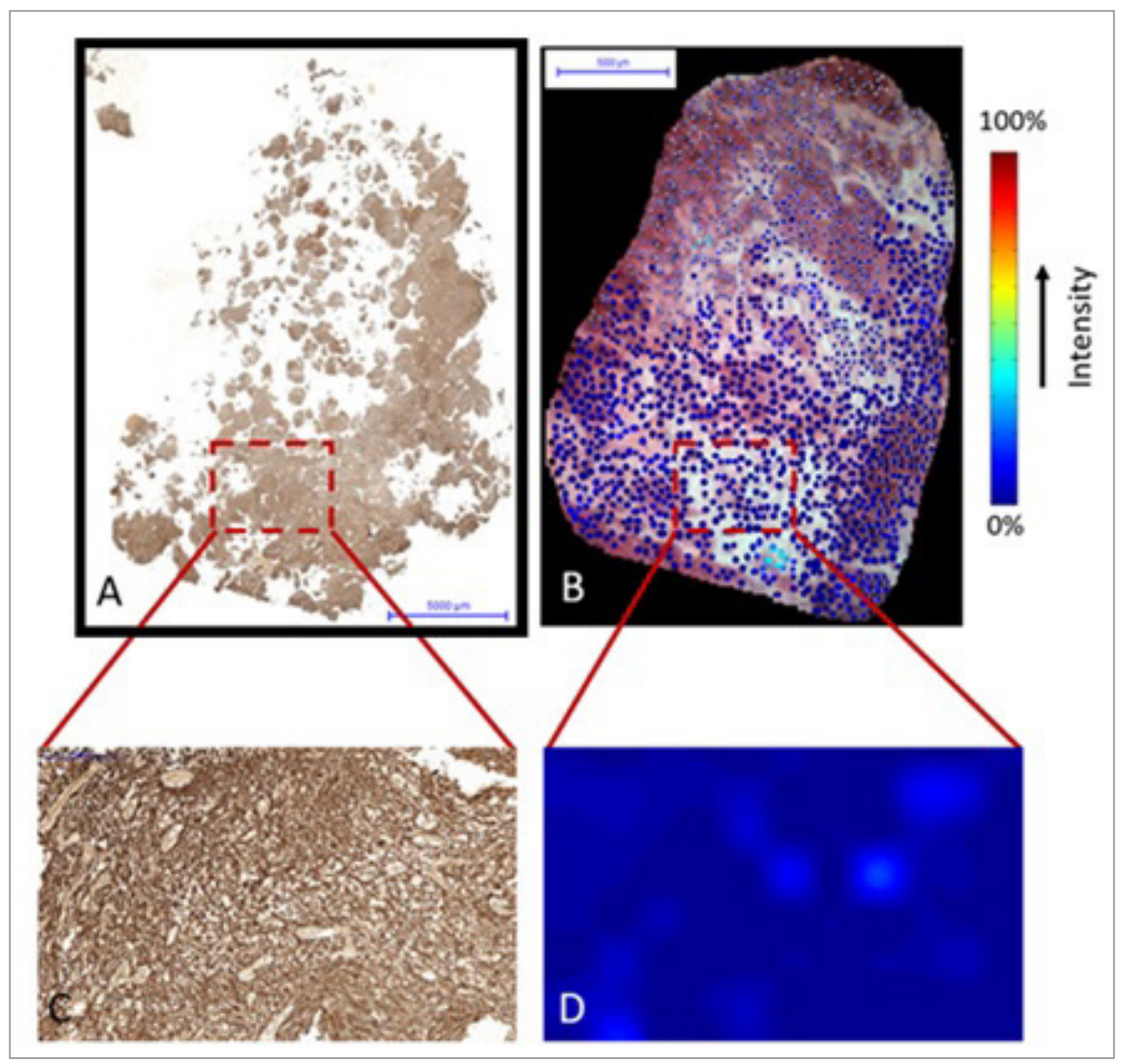

Figure 3. Immunohistochemistry and MALDI-MSI for the molecular marker GFAP. Comparative overlapping of images between the immunohistochemistry labeling for GFAP (A), and the molecular mapping of the same biomarker, generated by MSI (B). The pattern of reaction throughout the tissue is uniform and homogeneous, as characterized by the distribution of GFAP all over the nervous neoplastic tissue section. The selected region in (A) was magnified (C) to show the diffuse distribution pattern all over the tumor tissue in GBM, characterized by a brown labeling. The magnified image generated by MSI (Figure 3D), was characterized by low intensity blue spots, corresponding to the overall distribution of GFAP. The images GFAP distribution were produced by overlapping of the $m / z$ values of the tryptic peptides detected for this marker: $m / z$ 1697.79 (SYVSSGEMMVGGLAPGR), $m / z$ 1108.47 (AEMMELNDR), $m / z$ 986.52(ELQEQLAR), and $\mathrm{m} / \mathrm{z} 1208.58$ (EAASYQEALAR). The spatial distribution of GFAP was represented quantitatively in a relative scale, shown in the right side of the figure.

The Figures 4A and 4B show the pattern of labelling obtained by immunohistochemistry and the general profile of MALDI MSI, respectively, for the GBM marker S-100 over the GBM tissue section. The Figure 4C is showing the magnified image of the area assigned by the dashed lines in the Figure 4A; meanwhile, the figure 4D is showing the magnified image corresponding to the MALDI MSI of dashed rectangle assigned in Figure 4B. 


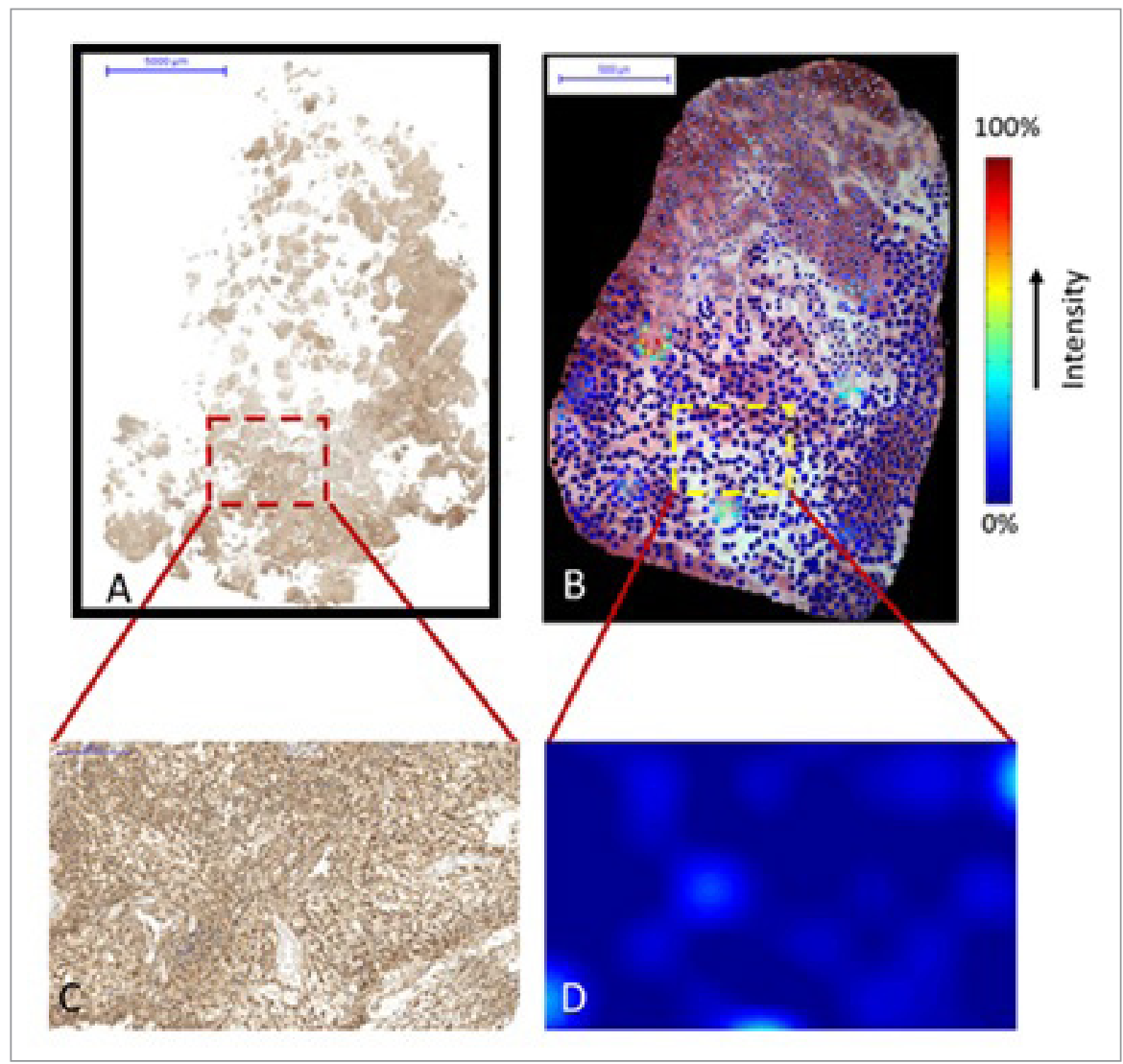

Figure 4. Immunohistochemistry and MALDI-MSI for the molecular marker S100. Comparative overlapping of images between the immunohistochemistry labeling for the S100 (A), and the molecular mapping of the same biomarker, generated by MSI (B). A pattern of uniform homogeneous reaction characterized the distribution of $\mathrm{S} 100$ protein all over the tissue section. The selected region in $(A)$ was magnified $(C)$ to show the diffuse distribution pattern all over the tumor tissue in GBM, characterized by a brown labeling. The magnified image generated by MSI (Figure 4D), was characterized by low intensity blue spots, corresponding to the distribution of $S 100$ protein. The images of $S 100$ distribution were produced by overlapping of the $\mathrm{m} / \mathrm{z}$ values of the tryptic peptides detected for this marker: $m / z 1691.98$ (ELLQTELSGFLDAQK), $\mathrm{m} / \mathrm{z} 761.36$ (DVDAVDK), and $\mathrm{m} / \mathrm{z} 2531.18$ (MGSELETAMETLINVFHAHSGK). The spatial distribution of $\mathrm{S} 100$ was represented quantitatively in a relative scale, shown in the right side of the figure.

The Figures 5A and 5B show the pattern of labelling obtained by immunohistochemistry and the general profile of MALDI MSI, respectively, for the GBM marker Ki-67 over the GBM tissue section. The Figure 5C is showing the magnified image of the area assigned by the dashed lines in the Figure 5A; meanwhile, the figure $5 \mathrm{D}$ is showing the magnified image corresponding to the MALDI MSI assigned by a dashed rectangle in Figure 5B. 


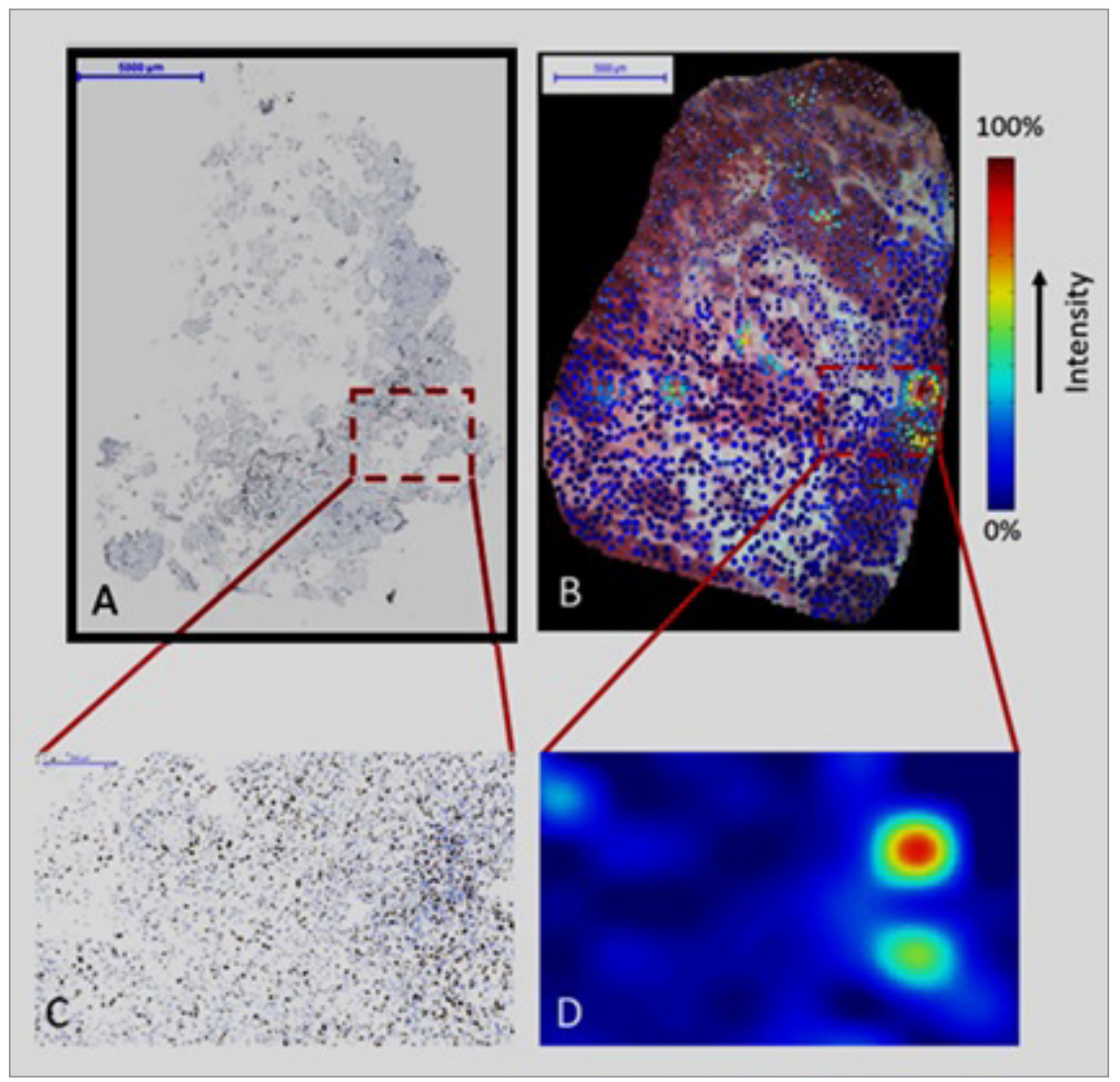

Figure 5. Immunohistochemistry and MALDI-MSI for the molecular marker Ki-67. Comparative overlapping of images between the immunohistochemistry labeling for the Ki67 protein as molecular marker of cellular proliferation (A), and the molecular mapping of the same biomarker, generated by MSI (B). A pattern of reaction characterized the distribution of Ki67 protein all over the tissue section, with areas of relatively low reaction pervaded with areas of high Ki67 reactivity (the "hot spots"). The selected region in (A) was magnified (C) to show the irregular cluster distribution pattern in the tumor tissue in GBM reflecting different cellular proliferation rates among different spots (brown/grey nuclear labeling). The image generated by MSI (Figure 5D) reveals areas of higher cellular proliferation ("hot spots") identified by their "hot colors", in the same pattern of spatial localization of the positive foci of the immunohistochemical reactions, spaced by negative or less positive areas, corresponding to the irregular distribution of Ki67 protein. The images of Ki67 distribution were produced by overlapping of the $\mathrm{m} / \mathrm{z}$ values of the tryptic peptides detected for this marker: $\mathrm{m} / \mathrm{z}$ 858.49 (EELLAVGK), m/z 1830.95 (ESADGLQGETQLLVSRK), $\mathrm{m} / \mathrm{z} 673.78$ (LTPSAGK), $\mathrm{m} / \mathrm{z} 2023.32$ (MPCQSLQPEPINTPTHTK), and $\mathrm{m} / \mathrm{z} 1862.94$ (TEAEQQITEVFVLAER). The spatial distribution of Ki-67 was represented quantitatively in a relative scale, shown in the right side of the figure.

\section{Discussion}

The outstanding achievements in current oncology includes the use of state-of-art neuroimaging technology, associated to aggressive surgical resections, new strategies in radiotherapy and chemotherapy. Despite to this, the malignant gliomas such as GBM continues challenging the advances in the modern medicine; the current prognosis for GBM patients is not good. The future of GBM therapy seems to depend on the studies at molecular and cellular levels, to improve our understanding about the genetics, biochemistry and metabolism of this disease. The identification of the genetic events and the regulatory pathways involved in the immunological responses of the tumors, as well as the understanding of the 
role of stem cells in tumor aggressiveness/resistance may enlighten the development newer strategies of therapy of this fatal disease. In this sense, the validation of MALDI Imaging technology to identify novel molecular markers, not depending of the development of highly selective antibodies, may contribute for the application of novel imaging strategies, improving the current knowledge in imaging diagnostics of GBM.

In the present study were used two complimentary strategies, i.e., immunohistochemistry and MALDI $\mathrm{MSI}$, both performed in histological sections of GBM tumors from the same patient. Despite the samples came from the same tumor, the treatment of GBM sections required for each approach is different. For MALDI-Imaging assays we obtained cuts of frozen fresh material with a mean thickness of $12 \mu \mathrm{m}$, while the tissue sections used in immunohistochemical reactions were fixed in formaldehyde, paraffin-included and cut into histological sections with $3 \mu \mathrm{m}$ thickness.

The results of in situ proteomic analysis in the GBM tumor sections performed in the present study identified proteins from different functional categories such as: organization/regulation of the cytoskeleton, adhesion cell-matrix / cellular differentiation, signal transduction, regulation of t-cell activation, regulation of immune response, energetic metabolism, protein degradation, cel-to-cell communication, transcriptional process.

It is important to emphasize that the use of immunohistochemistry (for the purpose of mapping proteins in tissue sections), requires the use of previously developed and produced primary antibodies, specific for each protein under investigation [24]. This fact limits severely the study to a few known proteins, which are markers for confirmation of histogenetic diagnosis or accessing the proliferation rate of the tumors [18]. Meanwhile, MALDI MSI is a technique that may be potentially applied to this situation, hypothetically without the use any standard protein, and does not requiring the use of any type of antibody, permitting more freedom of choice and a better chance to identify candidate proteins to become molecular prognostic/ diagnostic markers, or therapeutic targets [25]. The use of MALDI MSI generated from the overlapping of the spectra of all tryptic peptides detected and sequenced, resulted in a reliable mapping of the distribution of each molecular maker all over the tissue section.

However, for this purpose it is necessary to validate the use of MALDI MSI to the study of proteins related to GBM tumors; thus, a comparative study between both techniques was performed. Amongst the 25 proteins identified by in situ proteomic analysis, were identified five proteins which are well accepted standardized markers, with commercially available antibodies routinely used in surgical pathology to assist the diagnosis of GBM tumors by immunohistochemistry [26]: protein Ki-67, glial fibrillary acidic protein GFAP, protein S100-A, hematopoietic progenitor cell antigen CD34, and platelet endothelial cell adhesion molecule - CD31. Their detection and the exact location in GBM tissue sections were performed by both immunohistochemistry and MALDI MSI, and the comparative results are shown in Figures 1 to 5.

The markers CD31 and CD34 are characteristic of the vascular endothelial cells, localized in the inner lining of the blood vessels [27]. Blood vessels in glioblastomas form complex vascular glomeruloid structures that are part of histopathological criteria of this neoplasm. A careful observation of Figures 1 and 2 reveals the similar vascular pattern obtained both for CD31 and CD34, highlighting the classical glomeruloid formations of Glioblastomas (Figures 1A and 1C for CD31, and 2A and 2C for CD34) labeling both markers, as expected for proteins associated to endothelial tissues. The images of molecular mapping of these markers obtained by MALDI MSI (Figures 1B and 1D for CD31, and Figures 2B and 2D for CD $34)$ match well the immunohistochemical glomeruloid pattern. The results of figures $1 C$ and $1 D$, as well 2C and 2D, suggests that the markers CD31 and CD34 seem to be distributed all over the tumor section, and form spots of high concentrations of these markers, matching the immunohistochemical pattern of the glomeruloid formations.

The neural markers GFAP and S-100 tend to have distribution throughout the brain and also the neoplastic tissue, with less heterogeneity in their location in these target tissues. Both proteins are markers of histogenesis of this neoplasm in cases of uncharacteristic morphology $[7,8]$. These proteins have a nonhomogeneous tissue distribution, with areas of more and of less intense labeling, reflecting little differences of distribution [28]. The immunohistochemical patterns of detection of GFAP and S-100 (Figures 3A and 3C, and $4 \mathrm{~A}$ and $4 \mathrm{C}$, respectively), are expected for constitutive proteins in the nervous tissues and their tumors. 
The images of molecular mapping of these markers obtained by MALDI MSI (Figures 3B and 3D, and 4B and $4 \mathrm{D}$, respectively) match well the patterns obtained by immunohistochemistry, and even enhancing the little differences of concentration that are quite not detectable in the immunoassays. The results reported above are suggesting that GFAP and S-100 seems to be homogeneously distributed all over the tumor section, not forming hot spots due to the accumulation of high concentrations of the markers.

The immunohistochemical detection of Ki-67 (a cell proliferation marker) has a lower presence in tumors of low proliferation, and a higher presence in aggressive neoplasias such as GBM. Ki-67 is a nuclear antigen expressed in the G1, S, G2, and M phases of the cell cycle [29], thus labeling proliferating cells. A careful comparison of Figures $5 \mathrm{~A}$ and $5 \mathrm{~B}$ reveals a very similar pattern of distribution of the protein Ki-67 over the GBM section by both techniques, showing formation of clusters of high cell proliferation at different areas of the GBM section, also called "hot spots". The results shown in Figure 5A are corroborated by the results obtained by MALDI Imaging, shown in of Figure 5B; the clusters of immunohistochemistry labeling shown in Figure 5C are easily confirmed by the observation of similar hot spots in the image of the corresponding region of the tissue section, produced MALDI MSI (Figure 5D).

\section{CONCLUSIONS}

The results above are clearly indicating that the pattern of distribution of classical immunohistochemical molecular markers (protein Ki-67, GFAP, protein S100-A, CD34, and CD31) through the sections of GBM tumors are very similar to the pattern obtained by MALDI Imaging. This observation may validate the use of MALDI Imaging as an experimental strategy for mapping molecular markers of GBM tumors. The results above are indicating that the use of MALDI Imaging in medicine may provide access to an innovative and revolutionary technology that will allow studies in Proteomic Pathology. This will permit to design future projects of comparative studies of the constitutional proteins of normal and neoplastic cells, as well to identify and quantify cell-signaling proteins, with enormous potential of application in diagnosis and prognosis of cancer tumors.

\section{Acknowledgements}

This work was supported by a grant from the São Paulo State Research Foundation (FAPESP, BIOprospecTA program 2016/16212-5 and INCT Program/iii-CNPq/MCT). M.S.P. is researching for CNPq Proc. 305566/2017-2.

\section{Conflict of Interest}

The authors declare that they have no conflict of interest.

\section{Authorship agreement}

All authors have read the journal's authorship agreement and the manuscript has been reviewed by and approved by all named authors.

\section{Ethics approval and consent to participate}

Ethics approval was obtained from the local ethics committee. Written informed consent was obtained either from the patient or their appointed legal guardian.

\section{REFERENCES}

1. Dunn, G. P; Rinne, M. L.; Wykosky, J.; Genovese, G.; Quayle, S. N.; Dunn, I. F.; Pankaj K.; Agarwalla, P. J.; Chheda, M. G.; Campos, B. Genes Dev., 2012, 26, pp 756 - 784 (http://www.genesdev.org/cgi/ doi/10.1101/gad.187922.112).

2. Davis, F. G.; Kupelian, V.; Freels, S.; McCarthy, B.; Surawicz, T. Neuro-Oncology, 2001, 13, pp 152 168 (https://doi.org/10.1093/neuonc/3.3.152).

3. Dolecek, T. A.; Propp, J. M.; Stroup, N. E.; Kruchko, C. Neuro-Oncology, 2012, 4, pp 1 - 49 (https:// doi.org/10.1093/neuonc/nos218). 
4. Porter, K. R.; McCarthy, B. J.; Freels, S.; Kim, Y.; Davis, F. G. Neuro-Oncology, 2010, 12, pp 520 - 527 (https://doi.org/10.1093/neuonc/nop066).

5. Masui, K.; Cloughesy, T. F.; Mischel, P. S. Neuropathol. Appl. Neurobiol., 2012, 38, pp 271 - 291(https:// dx.doi.org/10.1111/j.1365-2990.2011.01238.x).

6. Stupp, R.; Mason, W. P.; van den Bent, M. J.; Weller, M.; Fisher, B.; Taphoorn, M. J. B.; Belanger, K.; Brandes, A. A.; Marosi, C.; Bogdahn, U.; et al. N. Engl. J. Med., 2005, 352, pp 987- 996 (https://www. nejm.org/doi/full/10.1056/NEJMoa043330).

7. Louis, D. L.; Ohgaki, H.; Wiestler, O. D.; Cavenee, W. K.; Burger, P. C.; Bernd, W.; Scheithauer, B. W.; Kleihues, P. Acta Neuropathol., 2007, 114, pp 97 - 109 (https://dx.doi.org/10.1007/s00401-007-0243-4).

8. Cloughesy, T. F.; Cavenee, W. K.; Mischel, P. S. Annu. Rev. Pathol. Mech. Dis., 2014, 9, pp 1-25 (https://dx.doi.org/10.1146/annurev-pathol-011110-130324).

9. Karsy, M.; Huang, T.; Kleinman, G.; Karpel-Massler, G. Front. Biosci., 2014,19, pp 1065 - 1087.

10. Ohgaki, H.; Kleihues, P. Clin. Cancer Res., 2013, 19, pp 764 - 772 (https://doi.org/10.1158/1078-0432. CCR-12-3002).

11. Thirant, C.; Gavard, J.; Junier, M. P.; Chneiweiss, H. Proteomics. Clin. Appl., 2013, 7, pp 79 - 90 (https://doi.org/10.1002/prca.201200102).

12. Gollapalli, K.; Ray, S.; Srivastava, R.; Renu, D.; Singh, P.; Dhali, S.; Dikshit, J. B.; Srikant, R.; Moivadi, A.; Srivastaya, S. Proteomics, 2012, 12, pp 2378 - 2390 (https://doi.org/10.1002/pmic.201200002).

13. Huse, J. T.; Holland, E. C. Nat. Rev. Cancer, 2010, 10, pp 319 - 331 (https://doi.org/10.1038/nrc2818).

14. Skjulsvik, A. J.; Mørk, J. N.; Torp, M. O.; Torp, S. H. Int. J. Clin. Exp. Pathol., 2014, 7, pp 8905 - 8910 (PMCID: PMC4313958).

15. Shiras, A.; Bhosale, A.; Shepal, V.; Shukla, R.; Baburao, V. S.; Prabhakara, K.; Shastry, P. Neoplasia, 2003, 5, pp 520 - 532 (https://dx, doi.org/10.1016/s1476-5586(03)80036-2).

16. Charalambous, C.; Chen, T. C.; Hofman, F.M. Neurosurg., 2006, 20,E22(https://doi.org/10.3171/foc.2006.20.4.e22).

17. McNamara, N. G.; Sahebjam, S.; Mason, W. P. Cancers, 2013, 5, pp 1103 - 1119 (https://doi. org/10.3390/cancers5031103).

18. Longuespe, R; Casadonte, R.; Kriegsmann, M.; Pottier, C.; Picard-de-Muller, G.; Delvenne, P. Proteomics Clin. Appl., 2016, 10, pp 701- 719 (https://doi.org/10.1002/prca.201500140).

19. Cole, L. M.; Clench, M. R. Proteomics Clin. Appl., 2015, 9, pp 335-341 (https://doi.org/10.1002/prca.201400103).

20. Lemaire, R.; Desmons, A.; Tabet, J. C.; Day, R.; Salzet, M.; Fournier, I. J. Prot. Res., 2007, 6, pp 1295 - 1305 (https://doi.org/10.1021/pr060549i).

21. Ronci, M.; Bonanno, E.; Colantoni, A.; Pieroni, L. Proteomics, 2008, 8, pp 3702 - 3714 (https://doi. org/10.1002/pmic.200701143).

22. Seeley, E. H.; Oppenheimer, S. R.; Mi, D.; Chaurand, P.; Caprioli, R. M. J. Am. Soc. Mass Spectrom., 2008, 19, pp 1069 - 1077 (https://doi.org/10.1016/j.jasms.2008.03.016).

23. Pratavieira, M.; Menegasso, A. R. S.; Esteves, F. G.; Sato, K. U.; Malaspina, O.; Palma, M. S. J. Proteome Res., 2018, 17 (7), pp 2358 - 2369 (https://doi.org/10.1021/acs.jproteome.8b00098).

24. Nuñez, F. J.; Mendez, F. M.; Garcia-Fabiani, M. B.; Pardo, J.; Edwards, M.; Pedro R. Lowenstein, P. R.; María G. Castro, M. G. J. Vis. Exp., 2019,143 (https://doi.org/10.3791/58931).

25. Briggs, M. T.; Condina, M. R.; Ho, Y. Y.; Everest-Dass, A. V.; Mittal, P.; Kaur, G.; Oehler, M. K.; Packer, N. H.; Hoffmann, P. Proteomics, 2019, 19 (21-22), e1800482 (https://doi.org/10.1002/pmic.201800482).

26. Cohen, A. L.; Colman, H. Cancer Treat Res., 2015, 163, pp 15 - 30 (https://doi.org/10.1007/978-3-319-12048-5_2).

27. Pisacane, A. M.; Picciotto, F.; Risio, M. Anal. Cell. Pathol., 2007, 29, pp 59 - 66.

28. Jung, C. S.; Foerch, C.; Schänzer, A.; Heck, A.; Plate, K. H.; Seifert, V.; Steinmetz, H.; Raabe, A.; Sitzer, M. Brain, 2007, 130, pp 3336 - 3341 (https://doi.org/10.1093/brain/awm263).

29. Mastronardi, L.; Guiducci, A.; Puzzilli, F.; Ruggeri, A. J. Neurosurg. Sci., 1999, 43, 263 - 270 (https:// doi.org/10.1023/A:1016261900413). 
Table S1. Proteomic data of the proteins identified in GMB tissue section

\begin{tabular}{|c|c|c|c|c|c|c|c|c|}
\hline & $\begin{array}{l}\text { Accession } \\
\text { code }\end{array}$ & $\begin{array}{c}\text { Protein } \\
\text { identification }\end{array}$ & Function & $\begin{array}{l}\text { Protein } \\
\text { Score }\end{array}$ & $\begin{array}{c}\% \\
\text { Sequence } \\
\text { coverage }\end{array}$ & Tryptic Peptides Sequenced & $m / z$ & $\begin{array}{c}\text { Charge } \\
\text { state }\end{array}$ \\
\hline 1 & A8MTL9 & $\begin{array}{c}\text { Serpin-like protein } \\
\text { HMSD }\end{array}$ & $\begin{array}{l}\text { Inhibitor of serine } \\
\text { endopeptidase }\end{array}$ & 36 & 38 & $\begin{array}{l}\text { TDTEYVLR } \\
\text { TANGLFGEK } \\
\text { VNSWVADK }\end{array}$ & $\begin{array}{l}996.64 \\
936.49 \\
918.70\end{array}$ & $\begin{array}{l}+1 \\
+1 \\
+1\end{array}$ \\
\hline 2 & P63313 & Thymosin beta-10 & $\begin{array}{l}\text { Organization of the } \\
\text { cytoskeleton }\end{array}$ & 31 & 38 & $\begin{array}{l}\text { MADKPDMGEIASFDK } \\
\text { ADKPDMGEIASFDKAK }\end{array}$ & $\begin{array}{l}1670.31 \\
1722.65\end{array}$ & $\begin{array}{l}+1 \\
+1\end{array}$ \\
\hline 3 & P47756 & $\begin{array}{l}\text { F-actin-capping } \\
\text { protein subunit } \\
\text { beta }\end{array}$ & $\begin{array}{l}\text { Organization of the } \\
\text { cytoskeleton }\end{array}$ & 38 & 25 & $\begin{array}{c}\text { MSDQQLDCALDLMR } \\
\text { VVGKDYLLCDYNR } \\
\text { LTSTVMLWLQTNKSGSGTMNLGGSLTR }\end{array}$ & $\begin{array}{l}1669.30 \\
1557.29 \\
2868.91\end{array}$ & $\begin{array}{l}+1 \\
+1 \\
+1\end{array}$ \\
\hline 4 & Q5TAT5 & $\begin{array}{l}\text { Collagen alpha-1 } \\
\text { chain }\end{array}$ & $\begin{array}{l}\text { Adhesion cell-matrix; } \\
\text { cellular differentiation }\end{array}$ & 33 & 15 & $\begin{array}{c}\text { GFPGFPGPIGLDGKPGHPGPK } \\
\text { GDMGLTGPPGQPGPQGQKGEK } \\
\text { GQCGEYPHRECLSSMPAALR } \\
\text { GEIGLPGPPGHDGEKGPR }\end{array}$ & $\begin{array}{l}2028.41 \\
2051.07 \\
2203.75 \\
1769.02\end{array}$ & $\begin{array}{l}+1 \\
+1 \\
+1 \\
+1\end{array}$ \\
\hline 5 & Q02223 & $\begin{array}{l}\text { Tumor necrosis } \\
\text { factor receptor } \\
\text { superfamily } \\
\text { member } 17\end{array}$ & $\begin{array}{l}\text { Immunity; receptor and } \\
\text { proto-oncogene }\end{array}$ & 32 & 58 & $\begin{array}{c}\text { GTNAILWTCLGLSLIISLAVFVLMFLLR } \\
\text { ISSEPLK } \\
\text { SKPKVDSDHCFPLPAMEEGATILVTTK } \\
\text { NTGSGLLGMANIDLEKSR } \\
\text { MLQMAGQCSQNEYFDSLLHACIPCQLR }\end{array}$ & $\begin{array}{l}3114.25 \\
3396.41 \\
932.51 \\
2051.07 \\
2993.76\end{array}$ & $\begin{array}{l}+1 \\
+1 \\
+1 \\
+1 \\
+1\end{array}$ \\
\hline
\end{tabular}


Table S1. Proteomic data of the proteins identified in GMB tissue section (Continuation)

\begin{tabular}{|c|c|c|c|c|c|c|c|c|}
\hline & $\begin{array}{l}\text { Accession } \\
\text { code }\end{array}$ & $\begin{array}{c}\text { Protein } \\
\text { identification }\end{array}$ & Function & $\begin{array}{l}\text { Protein } \\
\text { Score }\end{array}$ & $\begin{array}{c}\% \\
\text { Sequence } \\
\text { coverage }\end{array}$ & Tryptic Peptides Sequenced & $m / z$ & $\begin{array}{l}\text { Charge } \\
\text { state }\end{array}$ \\
\hline 6 & Q96QF1 & $\begin{array}{l}\text { RAB3A interacting } \\
\text { protein }\end{array}$ & Protein transportation & 38 & 17 & $\begin{array}{c}\text { LRSPSVLEVR } \\
\text { TLVLSSSPTSPTQEPLPGGK } \\
\text { STSSAMSGSHQDLSVIQPIVKDCK } \\
\text { EADLSLYNEFR } \\
\text { KCALTGQSK } \\
\text { LGYFKEEL }\end{array}$ & $\begin{array}{l}1154.40 \\
1995.04 \\
2517.45 \\
1355.77 \\
934.57 \\
997.41\end{array}$ & $\begin{array}{l}+1 \\
+1 \\
+1 \\
+1 \\
+1 \\
+1\end{array}$ \\
\hline 7 & Q16568 & $\begin{array}{l}\text { Cocaine- and } \\
\text { amphetamine- } \\
\text { regulated transcript } \\
\text { protein }\end{array}$ & $\begin{array}{l}\text { MAPKK activation; } \\
\text { positive regulation of } \\
\text { nerve impulses }\end{array}$ & 38 & 26 & $\begin{array}{c}\text { VRLLPLLGAALLLMLPLLGTR } \\
\text { LLPLLGAALLLMLPLLGTR } \\
\text { LLPLLGAALLLMLPLLGTRAQEDAELQPR }\end{array}$ & $\begin{array}{l}2258.31 \\
2003.57 \\
3141.17\end{array}$ & $\begin{array}{l}+1 \\
+1 \\
+1\end{array}$ \\
\hline 8 & Q99439 & Calponin-2 & $\begin{array}{l}\text { Cytoskeleton regulation; } \\
\text { cellular response to } \\
\text { mechanical stimulus }\end{array}$ & 32 & 30 & $\begin{array}{c}\text { NFDDATMKAGQCVIGLQMGTNK } \\
\text { HLYDPKNHILPPMDHSTISLQMGTNK } \\
\text { CASQVGMTAPGTRR }\end{array}$ & $\begin{array}{l}2341.45 \\
3018.22 \\
1449.44\end{array}$ & $\begin{array}{l}+1 \\
+1 \\
+1\end{array}$ \\
\hline 9 & P57075 & $\begin{array}{l}\text { Ubiquitin- } \\
\text { associated and } \\
\text { SH3 domain- } \\
\text { containing protein } \\
\text { A }\end{array}$ & $\begin{array}{l}\text { negative regulation of } \\
\text { T-cell receptor }\end{array}$ & 32 & 14 & $\begin{array}{c}\text { MAAGETQLYAKVSNK } \\
\text { SRSSPSLLEPLLAMGFPVHTALK } \\
\text { LSNLTRASFVSHYILQK } \\
\text { MYTFSLATDLNSR } \\
\text { DFENDPPLSSCGIFQSRIAGDALLDSGIR }\end{array}$ & $\begin{array}{l}1689.74 \\
2466.59 \\
2056.09 \\
1533.41 \\
3092.67\end{array}$ & $\begin{array}{l}+1 \\
+1 \\
+1 \\
+1 \\
+1\end{array}$ \\
\hline 10 & Q9P2W3 & $\begin{array}{l}\text { Guanine } \\
\text { nucleotide-binding } \\
\text { protein G }\end{array}$ & $\begin{array}{l}\text { Hormone-mediated } \\
\text { signalization pathway }\end{array}$ & 34 & 52 & $\begin{array}{l}\text { EVESLKYQLAFQR } \\
\text { YQLAFQREMASK }\end{array}$ & $\begin{array}{l}1689.74 \\
1470.71\end{array}$ & $\begin{array}{l}+1 \\
+1\end{array}$ \\
\hline
\end{tabular}


Table S1. Proteomic data of the proteins identified in GMB tissue section (Continuation)

\begin{tabular}{|c|c|c|c|c|c|c|c|c|}
\hline & $\begin{array}{l}\text { Accession } \\
\text { code }\end{array}$ & $\begin{array}{c}\text { Protein } \\
\text { identification }\end{array}$ & Function & $\begin{array}{l}\text { Protein } \\
\text { Score }\end{array}$ & \begin{tabular}{c|}
$\%$ \\
Sequence \\
coverage
\end{tabular} & Tryptic Peptides Sequenced & $m / z$ & $\begin{array}{l}\text { Charge } \\
\text { state }\end{array}$ \\
\hline 11 & Q4G0S7 & $\begin{array}{l}\text { Coiled-coil domain- } \\
\text { containing protein } \\
152\end{array}$ & unknown & 40 & 29 & $\begin{array}{c}\text { MDQSSEGCMKK } \\
\text { NNILDIQLEKSNCLLK } \\
\text { GENEQLKISADLIK } \\
\text { EEGYKK } \\
\text { EMEISELNAK } \\
\text { LRSQEK } \\
\text { SQEKEK } \\
\text { KLQHFQEEK }\end{array}$ & $\begin{array}{l}1274.76 \\
1857.04 \\
1557.29 \\
752.88 \\
1178.17 \\
759.08 \\
747.01 \\
1186.02\end{array}$ & $\begin{array}{l}+1 \\
+1 \\
+1 \\
+1 \\
+1 \\
+1 \\
+1 \\
+1\end{array}$ \\
\hline 12 & Q8WZ60 & Kelch-like protein 6 & $\begin{array}{c}\text { Signalization pathway of } \\
\text { B-cell receptor }\end{array}$ & 33 & 14 & $\begin{array}{c}\text { MLMAGQRGAWTMGDVVEK } \\
\text { TGDLVEILNGEKVK } \\
\text { HKPSER } \\
\text { FVAEVTCLDPLR } \\
\text { LPLTEHELESENK } \\
\text { TQCYDPSTNKWSLK } \\
\text { AAMPVEAKCINAVSFR }\end{array}$ & $\begin{array}{r}2010.62 \\
1514.10 \\
752.88 \\
1362.09 \\
1537.69 \\
1669.30 \\
1721.46\end{array}$ & $\begin{array}{l}+1 \\
+1 \\
+1 \\
+1 \\
+1 \\
+1 \\
+1\end{array}$ \\
\hline 13 & Q9Y463 & $\begin{array}{l}\text { Dual specificity } \\
\text { tyrosine- } \\
\text { phosphorylation- } \\
\text { regulated kinase } \\
\text { 1B }\end{array}$ & myoblast fusion to protein & 32 & 17 & $\begin{array}{c}\text { MAVPPGHGPFSGFPGPQEHTQVLPDVR } \\
\text { LSVDLIKTYK } \\
\text { LLELMNQHDTEMKYYIVHLK } \\
\text { HFMFR } \\
\text { NTHFRGVSLNLTR } \\
\text { MTGGRPPLPPPDDPATLGPHLGLR }\end{array}$ & $\begin{array}{l}2868.91 \\
1178.17 \\
2549.25 \\
752.88 \\
1514.10 \\
2642.29\end{array}$ & $\begin{array}{l}+1 \\
+1 \\
+1 \\
+1 \\
+1 \\
+1\end{array}$ \\
\hline
\end{tabular}


Table S1. Proteomic data of the proteins identified in GMB tissue section (Continuation)

\begin{tabular}{|c|c|c|c|c|c|c|c|c|}
\hline & $\begin{array}{l}\text { Accession } \\
\text { code }\end{array}$ & $\begin{array}{c}\text { Protein } \\
\text { identification }\end{array}$ & Function & $\begin{array}{l}\text { Protein } \\
\text { Score }\end{array}$ & $\begin{array}{c}\% \\
\text { Sequence } \\
\text { coverage }\end{array}$ & Tryptic Peptides Sequenced & $m / z$ & $\begin{array}{l}\text { Charge } \\
\text { state }\end{array}$ \\
\hline 14 & P19961 & Alpha-amylase 2B & Carbohydrate catabolism & 31 & 11 & $\begin{array}{c}\text { WVDIALECER } \\
\text { NMVTRCNNVGVR } \\
\text { NWGEGWGFMPSDR } \\
\text { MAVGFMLAHPYGFTR }\end{array}$ & $\begin{array}{l}1232.24 \\
1361.69 \\
1537.45 \\
1696.85\end{array}$ & $\begin{array}{l}+1 \\
+1 \\
+1 \\
+1\end{array}$ \\
\hline 15 & Q9NW81 & $\begin{array}{l}\text { ATP-synthase } \\
\text { subunit s-like } \\
\text { protein }\end{array}$ & ATP synthesis & 35 & 26 & $\begin{array}{c}\text { GIHRLGAAVAPEGNQK } \\
\text { LGAAVAPEGNQKK } \\
\text { TILQFLTNYFYDVEALRDYLLQR } \\
\text { CCHVDDWCLSRLYPLADSLQELSLAGCPR }\end{array}$ & $\begin{array}{l}1616.72 \\
1281.57 \\
2893.17 \\
3262.76\end{array}$ & $\begin{array}{l}+1 \\
+1 \\
+1 \\
+1\end{array}$ \\
\hline 16 & Q8NEM0 & Microcephalin & $\begin{array}{l}\text { Organizating center of } \\
\text { microtubulins }\end{array}$ & 33 & 11 & $\begin{array}{c}\text { QVTHVIFKDGYQSTWDK } \\
\text { ENLSPTSSQMIQQSHDNPSNSLCEAPLNISR } \\
\text { LSPTLSSTK } \\
\text { DLIKPHEELKK } \\
\text { TLVMTSMPSEKQNVVIQVVDK } \\
\text { VCAPENYLLSQ }\end{array}$ & $\begin{array}{r}2051.07 \\
3396.41 \\
932.51 \\
1348.66 \\
2344.97 \\
1235.79\end{array}$ & $\begin{array}{l}+1 \\
+1 \\
+1 \\
+1 \\
+1 \\
+1\end{array}$ \\
\hline 17 & Q14699 & Raftlin & Membrane protein & 37 & 17 & $\begin{array}{c}\text { FLEFTTLSAAELPGSSAVR } \\
\text { LIPEFIKK } \\
\text { FVGVIPQYHSSVNSAGSSAPVSTANSTEDARDAK } \\
\text { NQSPEPSSGPR } \\
\text { AGDMGNCVSGQQQEGGVSEEMK }\end{array}$ & $\begin{array}{l}1995.04 \\
986.45 \\
3448.93 \\
1154.40 \\
2242.40\end{array}$ & $\begin{array}{l}+1 \\
+1 \\
+1 \\
+1 \\
+1\end{array}$ \\
\hline
\end{tabular}


Menegasso, A. R. S.; Pratavieira, M.; dos Santos, L. D.; Lima, F. O.; Moraes, M. P. T.; Zanini, M. A.; Palma, M. S.

Table S1. Proteomic data of the proteins identified in GMB tissue section (Continuation)

\begin{tabular}{|c|c|c|c|c|c|c|c|c|}
\hline & $\begin{array}{l}\text { Accession } \\
\text { code }\end{array}$ & $\begin{array}{c}\text { Protein } \\
\text { identification }\end{array}$ & Function & $\begin{array}{l}\text { Protein } \\
\text { Score }\end{array}$ & $\begin{array}{c}\% \\
\text { Sequence } \\
\text { coverage }\end{array}$ & Tryptic Peptides Sequenced & $m / z$ & $\begin{array}{l}\text { Charge } \\
\text { state }\end{array}$ \\
\hline 18 & Q9P021 & $\begin{array}{l}\text { Cysteine-rich PDZ- } \\
\text { binding protein }\end{array}$ & Cell junction & 38 & 42 & $\begin{array}{c}\text { MVCEKCEK } \\
\text { VCEKCEK } \\
\text { LNENKALTSK } \\
\text { ARFDPYGK } \\
\text { SSVHQPGSHYCQGCAYK }\end{array}$ & $\begin{array}{r}968.46 \\
837.73 \\
1116.73 \\
1032.05 \\
2010.72\end{array}$ & $\begin{array}{l}+1 \\
+1 \\
+1 \\
+1 \\
+1\end{array}$ \\
\hline 19 & Q1L5Z9 & $\begin{array}{l}\text { LON peptidase } \\
\text { N-terminal domain } \\
\text { and RING finger } \\
\text { protein }\end{array}$ & $\begin{array}{l}\text { ATP-dependent } \\
\text { proteolysis }\end{array}$ & 38 & 13 & $\begin{array}{c}\text { EFLYCLALNPECNSVK } \\
\text { VMCEVLFSATANVHENLTSSIQSR } \\
\text { NFNITVLAEELIFRYLPDELSDR } \\
\text { RIYDEEMSELSNLTR }\end{array}$ & $\begin{array}{l}1841.89 \\
2650.88 \\
2766.79 \\
1854.87\end{array}$ & $\begin{array}{l}+1 \\
+1 \\
+1 \\
+1\end{array}$ \\
\hline 20 & Q9Y5Z7 & Host cell factor 2 & $\begin{array}{l}\text { co-activator of } \\
\text { transcription process }\end{array}$ & 38 & 12 & $\begin{array}{c}\text { GDIPPGCAAHGFVCDGTR } \\
\text { GVVPSPRESHTAVIYCK } \\
\text { MDPHRQGSNNIVPNSINDTINSTK } \\
\text { VETHATATPFSKETPSNPVATVK } \\
\text { VAAINGCGIGPFSKISEFK }\end{array}$ & $\begin{array}{l}1771.94 \\
1841.89 \\
2650.88 \\
2411.29 \\
1937.37\end{array}$ & $\begin{array}{l}+1 \\
+1 \\
+1 \\
+1 \\
+1\end{array}$ \\
\hline 21 & P46013 & $\begin{array}{l}\text { Proliferation } \\
\text { marker protein } \\
\text { Ki-67 }\end{array}$ & $\begin{array}{c}\text { to maintain individual } \\
\text { mitotic chromosomes } \\
\text { dispersed in the cytoplasm } \\
\text { following nuclear envelope } \\
\text { disassembly }\end{array}$ & 61 & 3 & $\begin{array}{c}\text { EELLAVGK } \\
\text { MPCQSLQPEPINTPTHTK } \\
\text { LTPSAGK } \\
\text { ESADGLQGETQLLVSRK } \\
\text { TEAEQQITEVFVLAER }\end{array}$ & $\begin{array}{r}858.49 \\
2023.32 \\
673.78 \\
1830.95 \\
1862.94\end{array}$ & $\begin{array}{l}+1 \\
+1 \\
+1 \\
+1 \\
+1\end{array}$ \\
\hline
\end{tabular}


Table S1. Proteomic data of the proteins identified in GMB tissue section (Continuation)

\begin{tabular}{|c|c|c|c|c|c|c|c|c|}
\hline & $\begin{array}{c}\text { Accession } \\
\text { code }\end{array}$ & $\begin{array}{c}\text { Protein } \\
\text { identification }\end{array}$ & Function & $\begin{array}{c}\text { Protein } \\
\text { Score }\end{array}$ & $\begin{array}{c}\% \\
\text { Sequence } \\
\text { coverage }\end{array}$ & Tryptic Peptides Sequenced & $m / z$ & $\begin{array}{c}\text { Charge } \\
\text { state }\end{array}$ \\
\hline 22 & P14136 & $\begin{array}{c}\text { Glial fibrillary acidic } \\
\text { protein } \\
\text { (GFAP) }\end{array}$ & $\begin{array}{l}\text { is a cell-specific } \\
\text { marker that, during the } \\
\text { development of the } \\
\text { central nervous system, } \\
\text { distinguishes astrocytes } \\
\text { from other glial cells. }\end{array}$ & 75 & 12 & $\begin{array}{c}\text { SYVSSGEMMVGGLAPGR } \\
\text { AEMMELNDR } \\
\text { ELQEQLAR } \\
\text { EAASYQEALAR }\end{array}$ & $\begin{array}{l}1697.79 \\
1108.47 \\
986.52 \\
1208.58\end{array}$ & $\begin{array}{l}+1 \\
+1 \\
+1 \\
+1\end{array}$ \\
\hline 23 & P23297 & Protein S100-A & $\begin{array}{l}\text { binds calcium but binds } \\
\text { zinc very tightly-distinct } \\
\text { binding sites with different } \\
\text { affinities exist for both ions } \\
\text { on each monomer }\end{array}$ & 83 & 53 & $\begin{array}{c}\text { ELLQTELSGFLDAQK } \\
\text { DVDAVDK } \\
\text { MGSELETAMETLINVFHAHSGK }\end{array}$ & $\begin{array}{l}1691.98 \\
761.36 \\
2531.18\end{array}$ & $\begin{array}{l}+1 \\
+1 \\
+1\end{array}$ \\
\hline 24 & P28906 & $\begin{array}{l}\text { Hematopoietic } \\
\text { progenitor cell } \\
\text { antigen CD34 }\end{array}$ & $\begin{array}{l}\text { Possible adhesion } \\
\text { molecule with a role in } \\
\text { early hematopoiesis by } \\
\text { mediating the attachment } \\
\text { of stem cells to the bone } \\
\text { marrow extracellular } \\
\text { matrix or directly to } \\
\text { stromal cells }\end{array}$ & 78 & 19 & $\begin{array}{c}\text { PSLSPGNVSDLSTTSTSLATSPTK } \\
\text { PYTSSSPILSDIK } \\
\text { LGILDFTEQDVASHQSYSQK } \\
\text { SWSPTGER }\end{array}$ & $\begin{array}{r}2348.18 \\
1407.73 \\
2266.09 \\
919.42\end{array}$ & $\begin{array}{l}+1 \\
+1 \\
+1 \\
+1\end{array}$ \\
\hline 25 & P16284 & $\begin{array}{l}\text { Platelet endothelial } \\
\text { cell adhesion } \\
\text { molecule } \\
\text { (CD31) }\end{array}$ & $\begin{array}{l}\text { Cell adhesion molecule } \\
\text { which is required for } \\
\text { leukocyte transendothelial } \\
\text { migration under most } \\
\text { inflammatory conditions }\end{array}$ & 67 & 8 & $\begin{array}{c}\text { SLPDWTVQNGK } \\
\text { PELESSFTHLDQGER } \\
\text { EQEGEYYCTAFNR } \\
\text { DTETVYSEVR }\end{array}$ & $\begin{array}{l}1244.62 \\
1744.81 \\
1609.65 \\
1198.55\end{array}$ & $\begin{array}{l}+1 \\
+1 \\
+1 \\
+1\end{array}$ \\
\hline
\end{tabular}

